\title{
DIVERSITY OF INSECT POLLINATORS VISITING BOERHAVIA DIFFUSA L. (NYCTAGINACEAE) A COMMON WEED IN VIRUDHUNAGAR BLOCK, TAMIL NADU
}

\author{
R. SREEBHA ${ }^{1}$ \& G. DARLING FEMI ${ }^{2}$ \\ ${ }^{1}$ Department of Botany, V.V. Vanniaperumal College for Women, Tamil Nadu, India \\ ${ }^{2}$ Department of Botany, Nesamony Memorial Christiancollege, Marthandam. Tamil Nadu, India
}

Insect pollinators are ecologically important in the ecosystem and essential for pollination, and to maintain valuable plant regeneration. The plant-pollinator relationships not only enhance the probability of cross pollination but also improve pollinator efficiency. Nevertheless, the evidences overwhelming, that wild pollinators declining around the world as a result of habitat loss and fragmentation, lack of forage due to mono-cropping and widespread use of pesticides. Consequently, the need to conserve for the efficient utilization of useful biodiversity such as pollinators and to gather species-specific baseline information on floral host plants preferences, seasonal dynamics, ecological relationships with host plant and environmental factors. Hence the data is based on insect pollinators visiting one of the wild medicinal plants, Boerhavia diffusa L., commonly called Hogweed with pink colored flowers blossomed throughout the year. This research has identified 4 Orders of Lepidoptera, Hymenoptera, Diptera and Coleoptera with 14 species of insects comes under 9 Families. Pseudapis oxybeloides Smith. (Soil nesting Bee) an abundant species in the study area and Zizula hylax Fabricius (Tiny grass blue butterfly) active throughout the year. Accordingly, the documentation to conservation programmes for insect pollinators and wild medicinal plants that would also indirectly benefit other crop pollinations too. However globally, many plants are under threat due to human population and industrial development and their fate depends upon preserving the mutualistic relationships with pollinators.
\end{abstract}

KEYWORDS: Insect pollinators, Boerhavia diffusa, Pseudapis oxybeloides, Zizula hylax, Documentation, Conservation

Received: Jun 10 2020; Accepted: Jul 01, 2020; Published: Aug 03, 2020; Paper Id.: IJBRDEC20202

\section{INTRODUCTION}

The insect pollinators play a huge role in plant reproduction. Since three-fourths of the world's flowering plants and 35 per cent of the world's food crop depends on pollinators to reproduce, it is essential for pollinators to thrive. Conversely the insect populations are threatened by habitat destruction and fragmentation, land conversion and climate change. The Virudhunagar Block (Latitude $9^{\circ} 62^{`} \mathrm{~N}$ and Longitude $77^{\circ} 93^{\prime} \mathrm{E}$ ) is one of the South Interior Tamil Nadu (SITN) District (Fig.1), with very low rainfall. Around 14 species of insects identified include butterflies, moths, wasps, honey bees, hoverflies, ants and lady beetleswhich come under 4 orders and 9 families. Accordingly, the perennial creeping herbaceous plant Boerhavia diffusa L., one among 40 species widely distributed in tropical and subtropical areas and warm climates, which grows throughout the tropical regions of Africa and Asia with high medicinal value. In Ayurveda, the B. diffusa L., recognized as 'Punarnava' means renew the body. Nonetheless, the phytochemical, pharmacological, experimental and clinical investigations were conducted by many researchers on the aerial parts and root of this plant. The leaves of $B$. diffusa $\mathrm{L}$., is used as a green vegetable in many parts of India. It is used by tribal people in India and in Unani medicine in Arab countries. Still, in most of the 
cultivation area, B. diffusa L.,was found as a weed after the rainy season and the farmers found it hard to remove the firmly rooted plant. While, most of them consider this plant group as a weed, some insects consider it as a nectariferous herb as observed in the study area. Most bee taxa especially, Pseudapis oxybeloides Smith. and the Paragus sp., are threatened by factors such as habitat degradation, agricultural strengthening by increased use of herbicides which can affect wild flower numbers and the misuse of insecticides. The nectaries located on the inner side of the staminal tube of Nyctaginaceae have nectariferous cells that are densely cytoplasmic and contain numerous starch grains [8]. The plants were scored as bee foraging species when at least three honeybees had visited to the flowers within the period of 10 minutes [13]. The insects are the best indicator of climatic conditions, the interaction between plants and insect relationship based on colour and size of the flower.

\section{MATERIALS AND METHODS}

2.1. Study Area: The study area was Virudhunagar block, mostly with black loamy soil and the rain fed crops such as Cotton, Pulses, Oilseeds, Black gram, Paddy, Cowpea, Cholam, Cumbu, Ragi, Millets, Maize, Sunflower, Groundnut and Sugarcane were cultivated, which do not require much irrigation. The climate of the region is semi-arid tropical monsoon type, generally hot dry and the temperature ranges from $21^{\circ} \mathrm{C}$ to $40^{\circ} \mathrm{C}$. Besides the bulk of the rainfall is received during the North East Monsoon in the months of October, November and December, then the pleasant weather, which is during the period from October to January. The forest area of this district covers the eastern slopes of Western Ghats and only $5.99 \%$ of the total geographical area is under forest with many rare and endemic varieties of flora found along the mountain slopes.

2.2. Boerhavia diffusa L., taxonomic study: The taxonomic studies for identification of species was done with the Photographic documentation (Fig.2) and the Herbarium was maintained. The flowering phenology was monitored at each study site, in addition, by selecting 10 inflorescence each with 5 to 6 flowers, soaked in $1 \mathrm{ml}$ of distilled water for 10 minutes, squeezed and then measured using a hand refractometer, in the morning as the highest nectar volume identified as 1 to 3 brix.

2.3. Insect Diversity Study: The plants B. diffusa L. visited by insect pollinators. Meantime, the identification was with the patterns based on their foraging activity, abundant, wing span and mode of flight. The observations were made for a period of January to June 2020 and between 9 a.m. to 1 p.m. Altogether observations made of clear, warm climate and Photographic documentation was done (Fig.3). Subsequently, the insects were identified using available literatures besides referring the species classification and scientific names with their common names. The diversity of species visiting B.diffusa L., in each month, abundance and its percentage of species diversity in each family was tabulated.

\section{RESULT}

The ensuing section presents the data about pollinators that frequently visit flowers in search of nectar or pollen and instinctively deposit pollen from previously visited plants which then use this deposited pollen to produce a fruit or seed. However, the nectar is presented in special nectary such a way that makes it available only specific pollinator species. Meanwhile, the order: Lepidoptera and the Hymenoptera show the high and equal percentage of species diversity visiting Boerhavia diffusa L., followed by very low in order: Coloeptera and Diptera (Chart. 1). The data ensures the Order: Hymenoptera shows the richness of species visiting B. diffusa L., plants, since the solitary bee or soil nesting bee Pseudapis oxybeloides Smith., belongs to Family: Halictidae, the common number of individual species naturally seen throughout the year, but the hoverfly bee Paragus species belongs to Order: Diptera dominantly seen in the months of March and April 
(Table.2),. Subsequently the high number of the wingless ant the Monomorium species (Pharaoh ant) abundance in the month of May, though it differs inforaging patterns as pollinators visiting inflorescence repeatedly for nectar results in very high levels of seed set also belongs to the Hymenoptera order (Table.3). Next the family Apidae, (the Chalcid wasp) Brachymeria sp. charted by the rarely sighted Potter wasp or Labus pusillus Vecht belongs to the family: Vespidae, also Lagioglossum sp. and Ceylalictus sp. (Sweat bee) which seems rare belongs to the same family of solitary bee. The order: Lepidoptera, as Lycaenidae displays the highest range of families with 4 butterfly species of Castalius rosimon Fabricius (Common pierrot), Freyeria trochylus Freyer (Grass jewel), Zizula hylax Fabricius (Tiny grass blue), Jamides alecto Felder (Metallic cerulean) in that Zizula hylax Fabricius (Tiny grass blue) being common throughout the year long. However, in the order: Lepidoptera the Eretmocera impactella Walker (Flower moth) is typically high in visiting the particular plant and Sphenarches sp. (Plume moth) seen rarely (Table.1).

\section{DISCUSSIONS}

The herb, Boerhavia diffusa L., a common weed, grows in the hot season and the flowers are more visible towards the insect pollinators after the decline of seasonal flowers such as Leucas aspera (Willd.) Link, Tridax procumbens (L) L, Ziziphus jujube Mill., Alternantha species etc. in the study area. Though the relationship of insect pollinators and the wild plants is generally based on the length of the corolla tube of the plant species coevolving with the length of the proboscis of insect pollinators, based on this information 4 species of butterfly family Lycaenidae are very particular in visiting this plant. The data reported Zizula and Freyeria species seen low, dry and intermediate zone mostly grasslands. Consequently, most of the butterfly species are generalist pollinators, which also implies that the habitat and host location are based on the visual cues like colour, flora or leaf chemical but many insects can complete development of a single plant or few host plants. Even though the flowers that attract insects and the pollens round about $60 \mu \mathrm{m}$, slightly spiny which easy for pollination, but often self-pollination by anthers contacting the stigma, as the flower closer, takes place. The Family: Halictidae took the second place in the family richness and the Pseudapis oxybeloides Smith., soil nesting bee dominant and throughout the year long, must conserve, and also can improve the aesthetic value of the landscape for the bee conservation and management activities which are inexpensive. Similarly, such practices are advisable for farmers that the food resources like wild plants for the flower-visiting bees by setting land aside at least 1-metre strip, also farmers should manage pesticide usage carefully to avoid poisoning. Nevertheless the roadside wild plants also indirectly play a major role in the protection of pollinator and the small tree Prosopis juliflora (Sw.) DC., mostly seen as a dominant plant spread throughout the bare land and identified as an invasive weed by some of the local people, also its eradication is a reason for wild plants to grow. Meanwhile, laws governing registration and use of plant protection products indirectly play a major role in the protection of pollinators.

\subsection{Data Analysis}

The diversified bee flora of the area supports beekeeping throughout the year. Although, the knowledge of honey plants is the most important factor in bee management and that the survival of honey bees is related to the abundance of bee plants, the data shows a marked decline in bees all over the world. The success of bee plants in a given area including botanical and palynological aspects provides information on flora and beekeeping potential. Due to the activity farmers get benefitted tremendously because of the ample presence of bee foraging plants. Lepidoptera is one of the most widespread and widely recognizable insect orders in the world. Though the soil nesting bee or Pseudapis oxybeloides Smith., belongs to Hymenoptera, as dominant bee species in the study area and managed for crop pollination in various regions around the Virudhunagar Block. Similarly, the small bee the Paragus species and ant pollinators studied in ecosystems has made them 
useful as indicator species in biodiversity studies. The lady beetle or the Pharoscymnus horni Wiese, regarded as important predators on multiple pests especially on mealybugs noticed as mostly seen pest in the study area. Though the Peucetia viridans Hentz (green lynx spider) is primarily of interest for its usefulness in agricultural pest management, distinctive in cotton fields, cultivating more in Virudhunagar District and as a bright green spider found on many kinds of shrub-like plants, also Syrphid flies seized by the attack of Lynx spider. Since the present studied plants visited by and show the abundance of hoverfly species which is a main food for this spider, it also maintains the ecological balance.

\section{CONCLUSIONS}

Insect pollinators are part of the life on the earth and an important component of its rich biodiversity. These collectively provide a wide range of environmental benefits, including pollination and natural pest control. The loss of insect diversity could potentially disrupt the plants pollinating interactions which negatively influence ecological and economic values for human beings and biodiversity. Now the present scenario of the excess use of pesticides, the looming threat of climate change and increasing pollution of the atmosphere may result into the disappearance or drastic decline in the numbers of insect pollinators such as a seasonal sensitive small hoverfly, also soil nesting bee Pseudapis oxybeloides Smith., commonly visiting medicinal herb B. diffusa L., in many areas. However, the Western Ghats of Tamil Nadu, recognized by UNESCO as one of the biodiversity hotspots of India and is not far away from the study area. By conserving insect pollinators will improve our whole environment for wildlife and enrich the lives of people now and in the future. Though the most work is done on the distribution and taxonomy of butterflies and rare information available on insect host plants relationships. Therefore, the present study gives a baseline for future plants-flora visitor relationships in the region.

\section{ACKNOWLEDGEMENTS}

I am grateful to Raju Kasambe and Alfred Daniel J. for help in identifying the specimens and relevant literature. I am also thankful to the Principal, V. V. Vanniaperumal College for Women (Autonomous), Virudhunagar, Tamil Nadu for facilities.

\section{REFERENCES}

1. AsifSajjad et al. (2019) Yearlong association of insect pollinator, Pseudapis oxybeloides with flowering plants: Planted forest vs. agricultural landscape. Saudi Journal of Biological Sciences, 26. 1799 - 1803.

2. Anilkumar Bhambhania and Ashokkumar Vaghela. (2014) Preliminary Study of Butterfly Diversity at Jasdan, Rajkot, India. Weekly Science Research Journal, 1: 28.

3. Cane, J. H. and V. J. Tepedino. (2001) Causes and extent of declines among native North American invertebrate pollinators: detection, evidence, and consequences. Conservation Ecology 5(1): 1 .

4. Kailash Chandra et al., (2019). INSECTA: HYMENOPTERA: APOIDEA (BEES). Zoological Survey of India. Fauna of Punjab. State Fauna Series, 23, 2019: 153-165.

5. Kasambe, Raju., (2018) Butterflies of Western Ghats. Second Edition. Published by author, Pp.372.

6. Krushnamegh Kunte. (2000) India-A lifescape butterflies of Peninsular India University Press (India) private limited.

7. Mahesh A.R. et. al. (2012) Detail Study on Boerhavia Diffusa Plant for its Medicinal Importance-A Review. Res. J. Pharmaceutical Sci, 1(1): 28-36.

8. María J. Nores et.al. (2013) Four o'clock pollination biology: nectaries, nectar and flower visitors in Nyctaginaceae from southern South America. Botanical Journal of the Linnean Society, 171: 551-567. 
9. Peiris M.U.H. et al. (2020). Diversity of butterflies in different habitat types of Seethawaka wet zone botanic gardens and Indikadamukalana forest reserve of Sri Lanka, Ceylon. Journal of Science, 49(1): 49-59.

10. Pooja Verma A and Lal V. K. (2014). Punarnava-A Natural Remedy by Ayurveda. Int J Pharm Pharm Sci., 6: 1-6.

11. Solomon Raju., A.J. and Purnachandra Rao., S. (2004). Flower Relationships and Pollination role of Pseudapis oxybeloides in some Indian Plants. Journal of the National Taiwan Museum, 57(1). 1 - 8

12. Ta Thi Thuy et al., (2019) A New Coumaronochromone From Boerhavia diffusa. Natural product communications, 14(6): 1-3.

13. Waykar Bhalchandra et al. (2014) Diversity of nectariferous and polleniferous bee flora at Anjaneri and Dugarwadi hills of Western Ghats of Nasik district (M. S.). India. Journal of Entomology and Zoology Studies, 2 (4): 244-249.

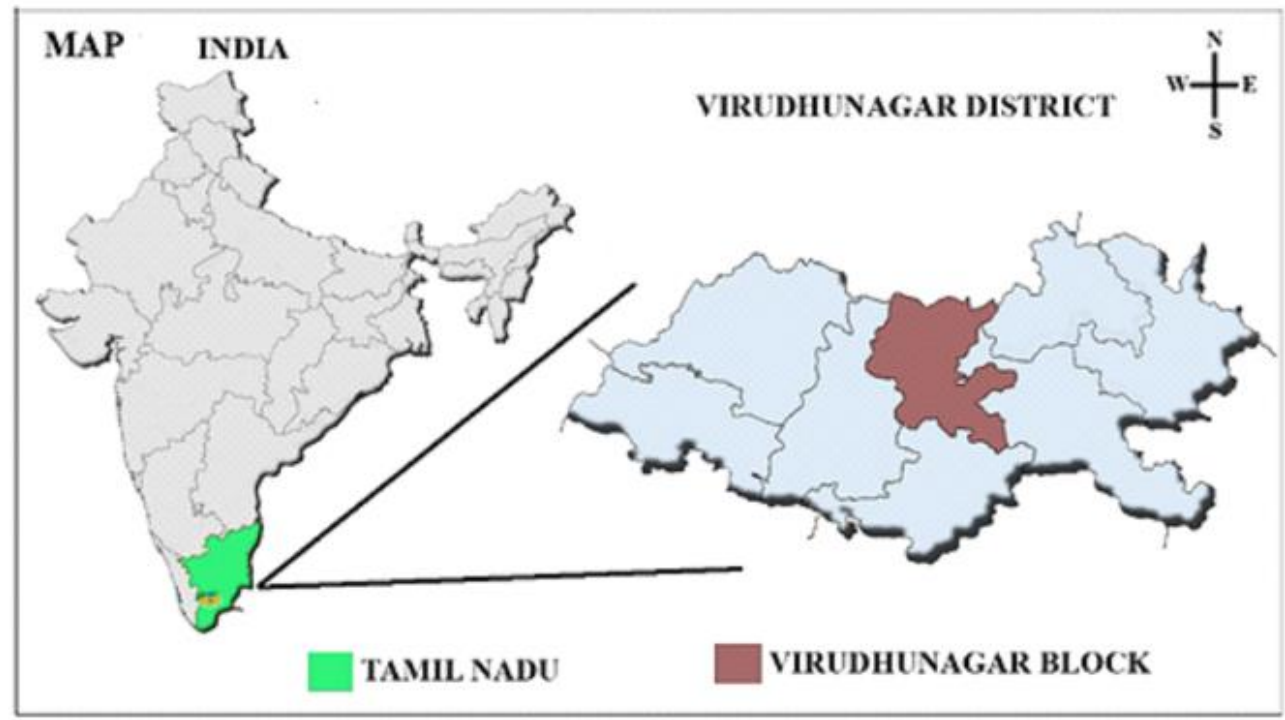

Figure 1: Map Showing the Virudhunagar block (Study Area)

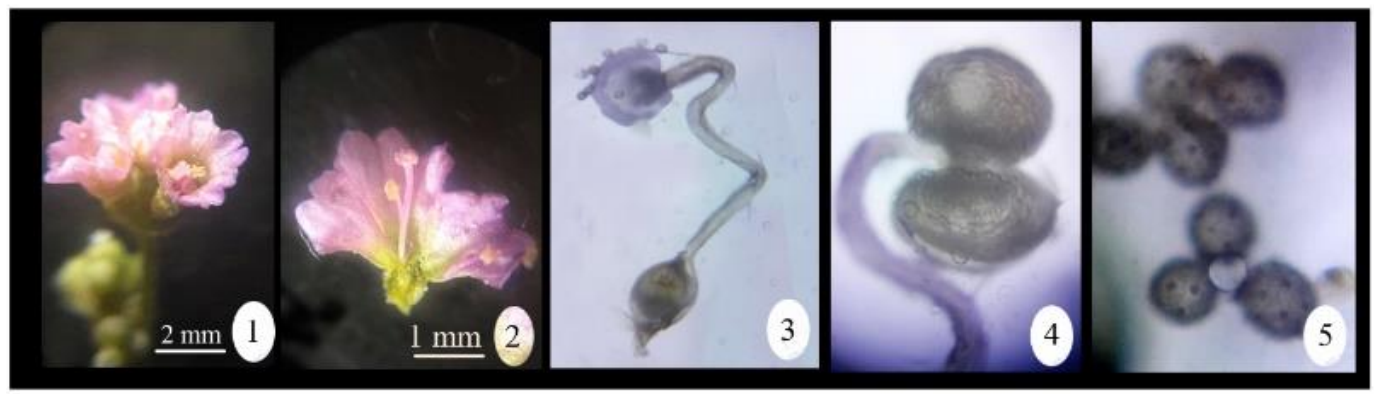

Figure 2: Boerhavia diffusa L.(1 - 5) 1. Flower 2. L. S. of Flower 3. Gynoecium 4. Stamen 5. Spores

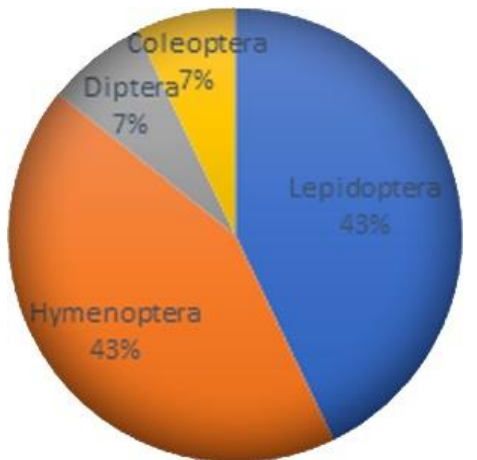

Chart 1: Percentage of Species Diversity in each family of Boerhavia diffusa $\mathrm{L}$. 

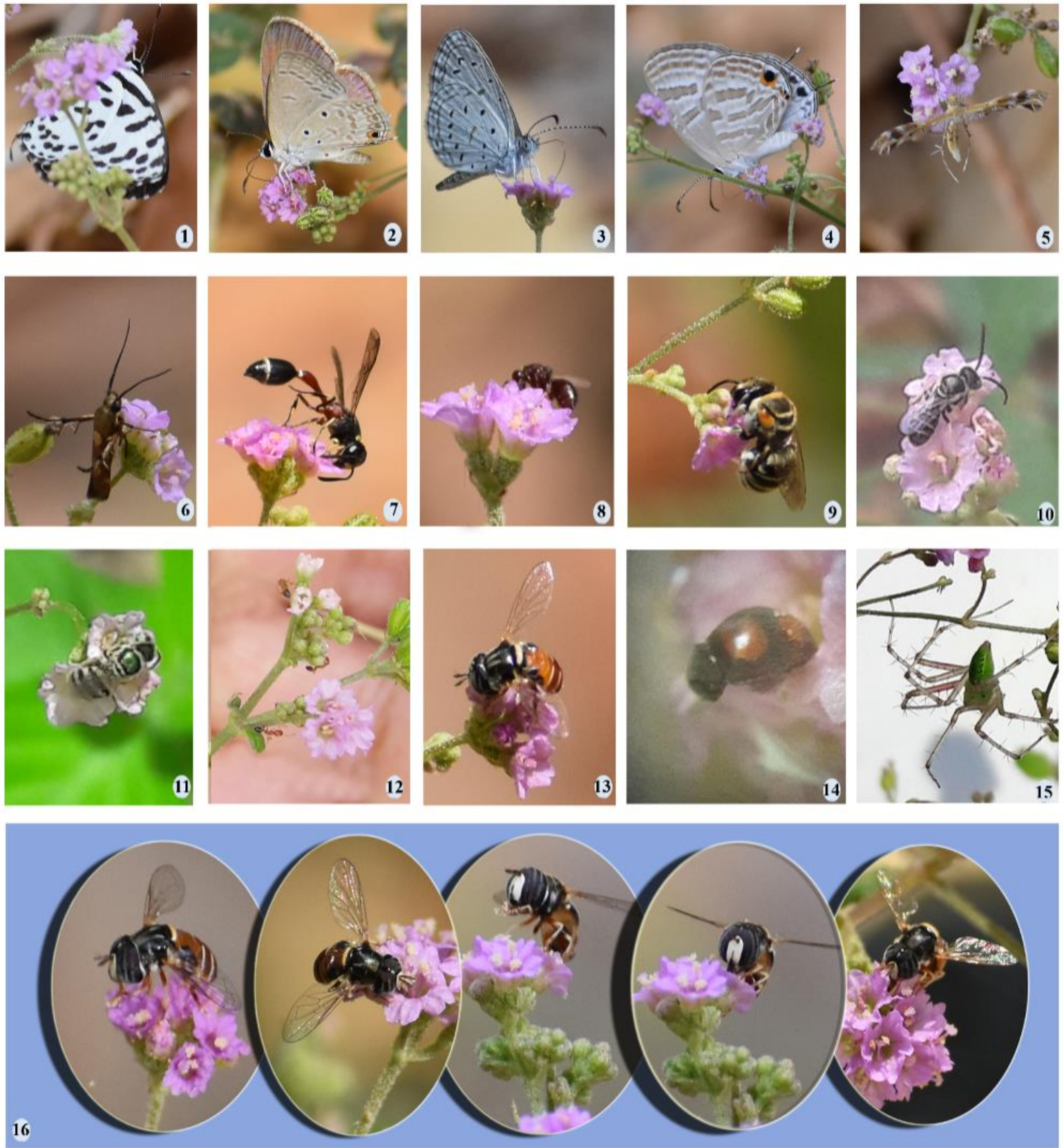

Figure 3: (1 - 16) Insect pollinators visiting Boerhavia diffusa L., Lepidoptera (1 - 6), Hymenoptera (7 - 12), Diptera (13), Coleoptera (14)

1. Castalius rosimon Fabricius (Common pierrot) 2. Freyeria trochylus Freyer(Grass jewel) 3. Zizula hylax Fabricius(Tiny grass blue) 4. Jamides alecto Felder (Metallic cerulean) 5. Sphenarches sp. (Plume moth) 6. Eretmocera impactella Walker (Flower moth) 7. Labus pusillus Vecht. (Potter wasp) 8. Brachymeria sp. (Chalcid wasp) 9. Pseudapis oxybeloides Smith. (Soil nesting bee) 10. Lagioglossum sp. (Sweat bee) 11. Ceylalictussp. (Sweat bee) 12. Monomorium sp. (Pharaoh ant) 13. Paragus sp. (Paragini) 14. Pharoscymnus horni Wiese (Ladybeetle) Arachnidae -15. Peucetia viridans Hentz (Green lynx spider) 16. Paragus sp. foraging B. diffusa L., for nectar. 


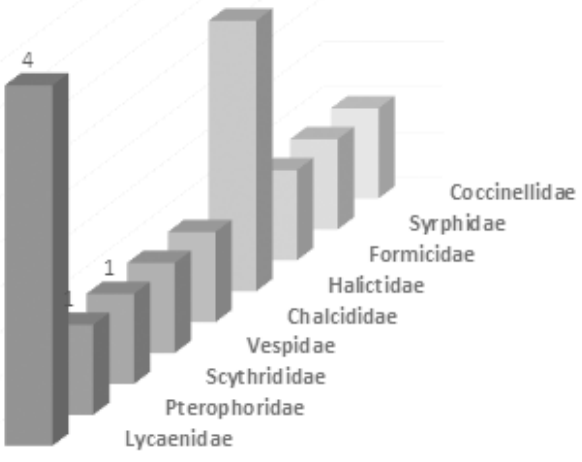

Chart 2: Species richness in each family visiting Boerhavia diffusa $\mathbf{L}$.

Table 1: Species abundance of insect pollinators visiting Boerhavia diffusa $\mathbf{L}$.

\begin{tabular}{|c|c|c|c|c|}
\hline Order & Family Name & Common Name & Scientific Name & $\begin{array}{c}\text { Abundanc } \\
\text { e }\end{array}$ \\
\hline \multirow[t]{6}{*}{ Lepidoptera } & Lycaenidae & Common Pierrot & Castalius rosimon Fabricius & Rare \\
\hline & & Grass jewel & Freyeria trochylus Freyer & Rare \\
\hline & & Tiny grass blue & Zizula hylax Fabricius & $\begin{array}{l}\text { Very } \\
\text { Common }\end{array}$ \\
\hline & & Metallic cerulean & Jamides alecto Felder & Rare \\
\hline & Pterophoridae & Plume moth & Sphenarches sp. & Rare \\
\hline & Scythrididae & Flower moth & Eretmocera impactella Walker & Common \\
\hline \multirow[t]{6}{*}{ Hymenoptera } & Vespidae & Potter wasp & Labus pusillus Vecht & Rare \\
\hline & Chalcididae & Chalcid wasp & Brachymeria sp. & Common \\
\hline & Halictidae & Soil nesting bee & Pseudapis oxybeloides Smith & $\begin{array}{l}\text { Very } \\
\text { Common }\end{array}$ \\
\hline & & Sweat bee & Lagioglossum sp & Rare \\
\hline & & Sweat bee & Ceylalictus sp. & Common \\
\hline & Formicidae & Pharaoh ant & Monomorium sp. & Common \\
\hline Diptera & Syrphidae & Paragini bee & Paragus sp. & Common \\
\hline Coleoptera & Coccinellidae & Lady beetle & Pharoscymnus horni Wiese & Rare \\
\hline
\end{tabular}

Table 2: Species distribution of Insect pollinators visiting Boerhavia diffusa L., -January to June 2020

\begin{tabular}{|l|c|c|c|c|c|c|}
\hline \multicolumn{1}{|c|}{ Scientific Name } & January & February & March & April & May & June \\
\hline Castalius rosimon Fabricius & - & + & + & + & + & - \\
\hline Freyeria trochylus Freyer & + & + & + & + & - & - \\
\hline Zizula hylax Fabricius & + & + & + & + & + & + \\
\hline Jamides alecto Felder & - & + & + & + & - & - \\
\hline Sphenarches sp. & - & - & + & - & - & - \\
\hline Eretmocera impactella Walker & + & + & + & + & + & - \\
\hline Labus pusillus Vecht & - & - & + & - & - & - \\
\hline Brachymeria sp. & - & + & + & + & + & + \\
\hline Pseudapis oxybeloides Smith & + & + & + & + & + & + \\
\hline Lagioglossum sp & - & - & - & - & + & + \\
\hline Ceylalictus sp. & - & - & - & - & + & + \\
\hline Paragus sp. & - & - & + & + & + & \\
\hline Monomorium sp. & - & - & - & - & + & + \\
\hline Pharoscymmus horni Wiese & - & - & - & - & + & + \\
\hline
\end{tabular}


Table 3: Richness of number in each species of insects visiting Boerhavia diffusa $\mathrm{L}$.

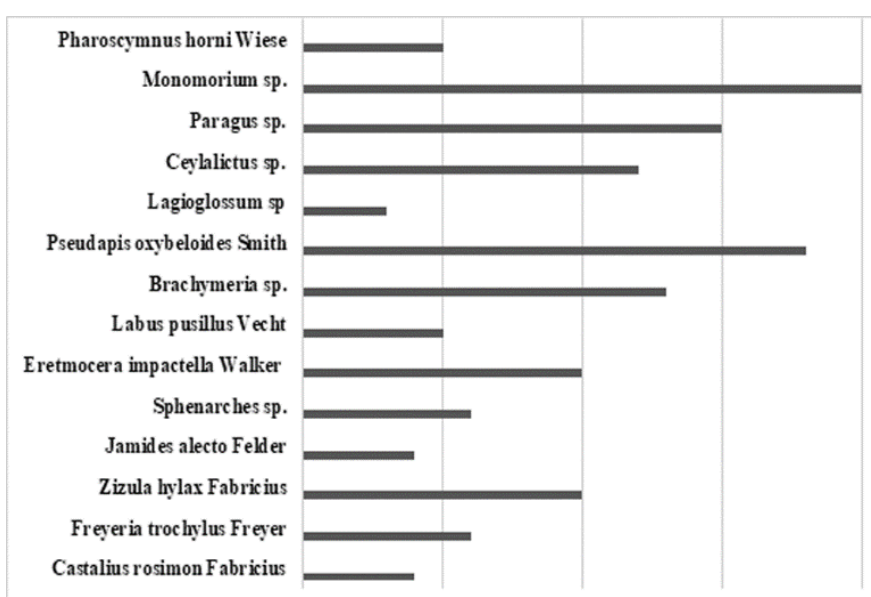

